\title{
Effects of agrotechnical factors on the quality and quantity of yield in winter wheat production
}

\author{
Zoltán Magyar $^{1}$ - Péter Pepó ${ }^{1}$ - Ernő Gyimes ${ }^{2}$ \\ ${ }^{1}$ University of Debrecen, Kerpely Kálmán Doctoral School, H-4032 Böszörményi road 138. Debrecen, \\ ${ }^{2}$ University of Szeged, Faculty of Engineering, Department of Food Engineering \\ magyarzoltan93@gmail.com
}

\begin{abstract}
SUMMARY
The present study was conducted to determine the effect of basic agrotechnical factors on the yield and quality of winter wheat. Two experiments were set in 2017/2018 growing season, where we studied the influence of different forecrops, fertilizing treatments and cultivars. 204 samples were measured with Single Kernel Characterization System and NIR grain analyser to determine protein (NIR-P), wet gluten (NIR-WG), Hardness Index (HI), kernel weight $(K W)$ and kernel diameter $(K D)$. Fertilizing had a significant effect on yield, KW, HI, NIR-P and NIR-WG, except KD. $N_{90} P K$ dosage was enough to realize yield potential for 6 out of 9 cultivars, but considering protein content $N_{150} P K$ dosage was needed. The forecrop had no significant influence on yield, KW, KD or HI, however sweet corn as previous crop had significant improving effect on NIR-P and NIR-WG compared to sunflower as forecrop. According to our data of correlation analysis, no negative relationship was found between yield and NIR-P, however HI was in medium positive correlation with NIR-P. The variety Vyckor had the highest yield, but in quality aspect, the highest NIR-P and NIR-WG values belonged to KG Kunhalom variety.
\end{abstract}

Keywords: winter wheat, forecrop, fertilizer, yield, quality

\section{INTRODUCTION}

Winter wheat is one of the most important cereal crops in Hungary because of its wide range of usability and great nutritional properties. The quality of wheat is a genetically coded characteristic, although it is necessary to choose the proper agrotechnical methods for realizing its crop potential. Yield and quality of wheat can be greatly affected by forecrop, which is favourable if it does not exploit the nutrient and water supplies of the soil (Ragasits, 1989). The quality parameters of wheat can be divided into two groups: 1) chemical properties, like protein and wet gluten content, sedimentation value; 2) physical ones, like colour, shape, weight and kernel hardness, these attributes determine together the milling and baking value (Pasha et al., 2010). More unfavourable ecological conditions are left behind by a forecrop, greater economic efforts are needed to create appropriate basic conditions for producing good quality crop (Hajdu, 1977). Maize is an acceptable forecrop, but the earliness of harvest is a substantial factor because of appropriate preparatory works (Koltay and Balla, 1982). In the 3-year experiment of Stoeva and Ivanova (2009), there was no significant effect of maize, sunflower and bean forecrop on wet gluten content. The yield was increased by average 2.3 tonne ha $^{-1}$ with $\mathrm{N}_{90} \mathrm{PK}$ treatment and sweet corn as forecrop, also the fertilizing improved significantly the protein and wet gluten content of the samples (Pepó, 2016). In the experiment of Borghi et al. (1995) maize and lucerne as previous crop had significant effect on yield and thousand kernel weight.

Considering the agrotechnical factors, one of the most important is the proper nutritional supply, which can be achieved by artificial fertilizing (Győri and Győriné, 1998). The usage of artificial fertilizers is affected by nutrient responses of the cultivated wheat genotype (Pepó, 2011), as a result the fundamental condition of economical wheat production is the selection of proper cultivar (Ágoston and Pepó, 2005). Linina and Ruza (2012); Litke et al. (2018) declared that $\mathrm{N}$ fertilizing has an improving effect on protein and wet gluten content.

It has been a well-known fact, that there is a negative correlation between kernel protein and yield, however both parameters can be improved simultaneously to a certain threshold with $\mathrm{N}$ fertilizing (Garrido-Lestache et al., 2004). These limits were 210 $\mathrm{kg} \mathrm{ha}^{-1} \mathrm{~N}$ for protein and wet gluten content and $180 \mathrm{~kg}$ $\mathrm{ha}^{-1} \mathrm{~N}$ for yield (Litke et al., 2018). The recommended optimal $\mathrm{N}$ fertilizer dosage is between $120-150 \mathrm{~kg} \mathrm{ha}^{-1}$ (Asthir et al., 2017; Horváth et al., 2014, Montemurro et al., 2007) to realize yield and quality potential of the genotype, to avoid nitrogen leaching out and plant lodging. Yield and protein content were significantly affected by cultivar-effect (Lukow and McVetty, 1991; Tayyar, 2010).

$\mathrm{N}$ fertilizing has a statistical influence on kernel hardness and protein content (Luo et al., 2000). According to Chantret et al. (2005) kernel hardness is an inherited trait, and it can determinate damaged starch content, flour yield and particle size distribution (Eliasson and Larsson, 1993). Kernel hardness depends on kernel size, protein and water content. Evidence of this conclusion is the measurements of Groos et al. (2004), where they find significant correlation between SKCS hardness index and NIR protein content. As stated by Szabó (2009) hardness index can be divided into three groups: 0-30: soft; 30-50 transition; above 50: hard wheat.

The quality of wheat has to be examined continuously, starting from wheat breeding, batch receipt and qualification, storage and before processing as well. For this purpose, NIR instruments are quick, well-used and reliable. Coefficient of determination 
values between NIR and conventional protein and wet gluten content is $r^{2}=0.992$ and $r^{2}=0.908$, respectively (Preston and Williams, 2003).

\section{MATERIALS AND METHODS}

The two experiments were set up at Látókép Experimental Farm of University of Debrecen in the $2017 / 2018$ growing season, which has a chernozem soil type. The soil has medium humus content, medium phosphorus and potassium content and neutral $\mathrm{pH}$. The forecrops of the experiment were sweet corn, maize and sunflower. Effect of three fertilizer levels (control, $\mathrm{N}_{90} \mathrm{P}_{67,5} \mathrm{~K}_{79,5} ; \mathrm{N}_{150} \mathrm{P}_{112,5} \mathrm{~K}_{132,5}$ ) was tested in $10 \mathrm{~m}^{2}$ plots in 4 repetitions. The $50 \%$ of nitrogen and the whole amount of the phosphorus and potassium were applied in autumn, the remaining $50 \%$ of the nitrogen fertilizer was applied in spring as top dressing. In the first experiment we examined the effect of 3 forecrops, 3 fertilizing treatments on 4 winter wheat cultivars (GK Öthalom, Mv Ispán, Ingenio and Hyland). In the second experiment we studied the different levels of fertilizer dosages with sweet corn forecrop on the following 9 winter wheat genotypes (GK Öthalom, Mv Ispán, GK
Csillag, KG Kunhalom, Vyckor, Ingenio, Hyland and Hybiza). Hyland (medium-early maturing type) and Hybiza (early maturing type) are hybrid genotypes with high yield potential.

The samples were treated by SLN Pfeuffer sample cleaner, then 204 cleaned samples were analysed with Single Kernel Characterization System 4100 (Hardness index, kernel weight and kernel diameter) and Mininfra Smart NIT grain analyser (Protein and wet gluten) at Cereal Research Non-profit Ltd., Szeged.

For processing the results of the measurements, $\mathrm{R}$ studio 3.6.1 version was used. For arranging and filtering the data, dplyer package (Wickham et al., 2019) was utilized. One-, two-, and three-way ANOVA with LSD post-hoc tests on 0.05 significance level of agricolae package (Mendiburu, 2019) were used. Also, Pearson's correlation analysis of IBM SPSS Statistics 22 program was performed. According to Tóthné (2011), there are tight, medium and loose correlations if the correlation coefficient is between $0.75-1,0.5-$ 0.75 and $0.25-0.5$, respectively. For graphical representation of Figure 1, Microsoft Excel 2016; while diamond plot of Python v3.7 version's Seaborn 0.9.0 library for Figure 2 was used.

Figure 1: Comparing the meteorological data of the cropping year and 30 year's average (Debrecen, Hungary, 2017/2018)

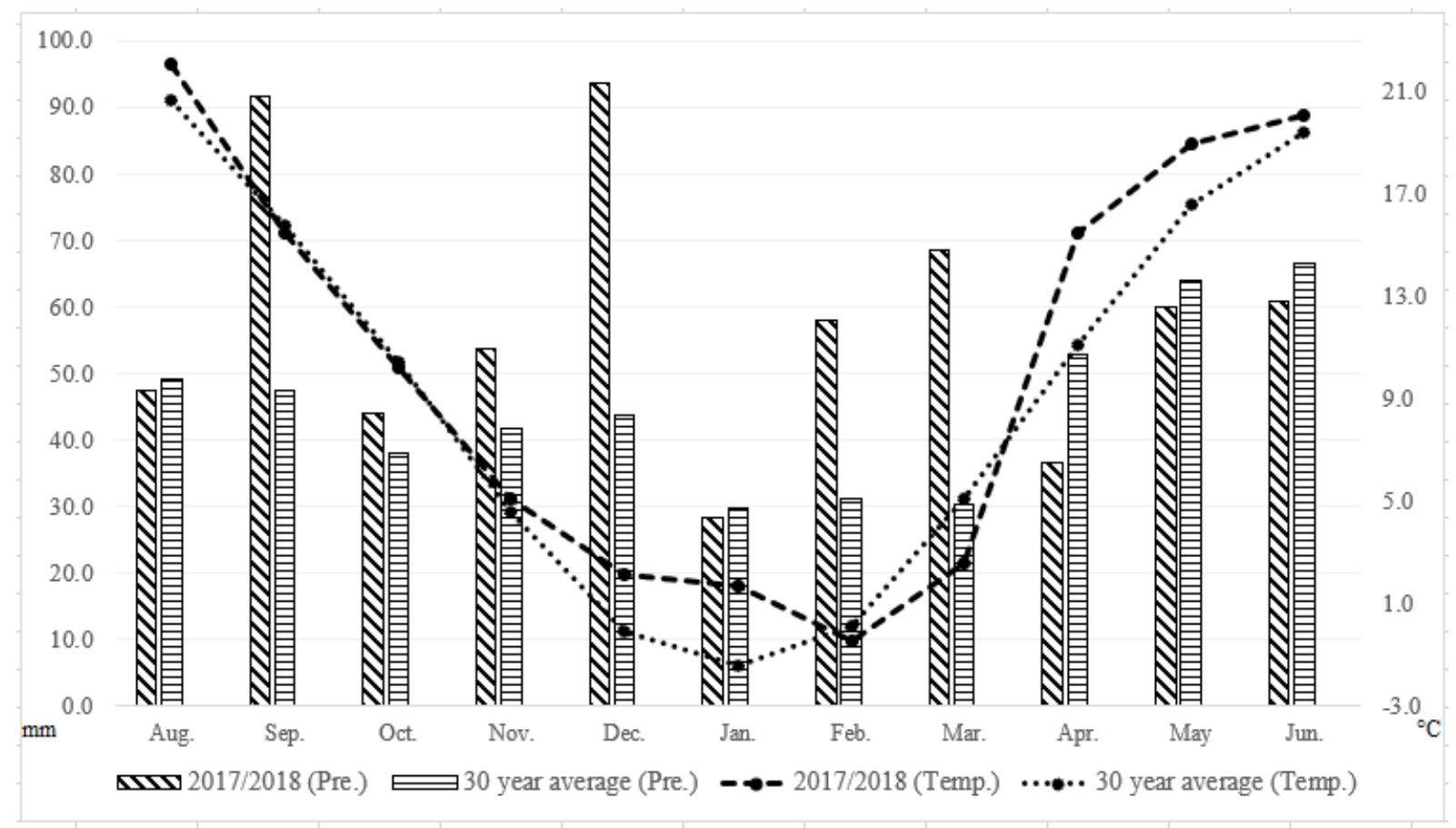

\section{RESULTS AND DISCUSSION}

\section{Cropping year}

Months of the autumn were mild, and gradually cooling down with an abundant amount of rainfall. The mild weather of December and January was also favourable for wheat plants. Due to the cold weather of February and March, the plants were underdeveloped in the beginning of April. It was very hot in April and May, which was unfavourable for the vegetative development of wheat and shortened the phenological stages. In May, the rainfall and the fall in temperature could not compensate the negative effects of the previous period. The summerlike weather of June shortened the grain filling and maturity periods (Figure 1). Total precipitation (642.4 $\mathrm{mm})$ of $2017 / 2018$ 
growing season was $148.5 \mathrm{~mm}$ more, while average temperature $\left(10.3^{\circ} \mathrm{C}\right)$ was $1^{\circ} \mathrm{C}$ more comparing to 30 year average $\left(493.9 \mathrm{~mm}, 9.3^{\circ} \mathrm{C}\right)$. To summarize, the weather of the 2017/2018 growing season was unfavourable for the vegetative and generative development of wheat plants (Pepó, 2018).

\section{Yield}

In the first experiment, forecrop had no significant effect on yield, however the best forecrop was sweet corn (avg. $7419 \mathrm{~kg} \mathrm{ha}^{-1}$ ), second one was sunflower $\left(6438 \mathrm{~kg} \mathrm{ha}^{-1}\right)$, the worst forecrop was maize $(5774 \mathrm{~kg}$ $\left.\mathrm{ha}^{-1}\right)$. Studying the yields separately in the aspect of fertilizing, yields of different cultivars did not differ significantly with control treatment, however with $\mathrm{N}_{90} \mathrm{PK}$ dosage Mv Ispán had higher yield compared to GK Öthalom, also in the case of $\mathrm{N}_{150} \mathrm{PK}$ dosage the yields of Mv Ispán and Hyland were significantly higher than GK Öthalom (Table 1). Examining the yield results with all the forecrops, the effect of fertilizing was significant. In addition, studying the yields separately, the yield of $\mathrm{N}_{90} \mathrm{PK}$ dosage was the highest, increasing the fertilizing dosage lowered the yield in the case of sweet corn forecrop (Control: 6292 $\mathrm{kg} \mathrm{ha}^{-1}$; $\mathrm{N}_{90} \mathrm{PK}$ : $8293 \mathrm{~kg} \mathrm{ha}^{-1} ; \mathrm{N}_{150} \mathrm{PK}$ : $\left.7671 \mathrm{~kg} \mathrm{ha}^{-1}\right)$. Yields of the samples grown after maize forecrop were significantly increased by both fertilizing treatments (Control: $2197 \mathrm{~kg} \mathrm{ha}^{-1}$; $\mathrm{N}_{90} \mathrm{PK}$ : $6962 \mathrm{~kg} \mathrm{ha}^{-1} ; \mathrm{N}_{150} \mathrm{PK}$ : $\left.8162 \mathrm{~kg} \mathrm{ha}^{-1}\right)$. Yields after sunflower forecrop were increased significantly by fertilizing compared to control ones, however $\mathrm{N}_{150} \mathrm{PK}$ did not improved statistically the yields more (Control: $3391 \mathrm{~kg} \mathrm{ha}^{-1}$; $\mathrm{N}_{90} \mathrm{PK}$ : $7555 \mathrm{~kg} \mathrm{ha}^{-1}$; $\mathrm{N}_{150} \mathrm{PK}: 8367 \mathrm{~kg} \mathrm{ha}^{-1}$ ).

In the second experiment with sweet corn forecrop, fertilizing significantly increased yield compared to control samples, but the highest yields were got with $\mathrm{N}_{90} \mathrm{PK}$ dosage, in fact this meant $1.83 \mathrm{t} \mathrm{ha}^{-1}$ yield surplus (Control: $6512 \mathrm{~kg} \mathrm{ha}^{-1}$; $\mathrm{N}_{90} \mathrm{PK}$ : $8342 \mathrm{~kg} \mathrm{ha}^{-1}$; $\mathrm{N}_{150} \mathrm{PK}: 8061 \mathrm{~kg} \mathrm{ha}^{-1}$ ), compared with the findings of Pepó (2016), where the yield surplus was $2.3 \mathrm{t} \mathrm{ha}^{-1}$. Comparing the cultivars, Vyckor $\left(8620 \mathrm{~kg} \mathrm{ha}^{-1}\right)$ and Hybiza $\left(8450 \mathrm{~kg} \mathrm{ha}^{-1}\right)$ had significantly higher yields compared to GK Öthalom. We realized the highest yield of GK Öthalom, Mv Ispán, Ingenio, Hyland, KG Kunhalom and Hybiza with $\mathrm{N}_{90} \mathrm{PK}$ dosage, while the yield of Vyckor, GK Csillag and Mv Nádor was increased with $\mathrm{N}_{150} \mathrm{PK}$ dosage as well. We divided the cultivars into 3 yield groups: 1 ) over $8 \mathrm{t} \mathrm{ha}^{-1} ; 2$ ) between $7-8 \mathrm{t} \mathrm{ha}^{-1}$ and 3$)$ under 7 tonne ha-1 . Mv Ispán $(8061 \mathrm{~kg}$ $\mathrm{ha}^{-1}$ ) and Hyland (8030 $\left.\mathrm{kg} \mathrm{ha}^{-1}\right)$ also exceeded the $8 \mathrm{t}$ $\mathrm{ha}^{-1}$ yield threshold, while GK Csillag (7814 $\left.\mathrm{kg} \mathrm{ha}^{-1}\right)$; Mv Ispán (7235 kg ha-1) and Ingenio (7105 kg ha-1) belonged to $2^{\text {nd }}$ group. Besides, KG Kunhalom (6867 $\left.\mathrm{kg} \mathrm{ha}^{-1}\right)$ and GK Öthalom (6479 $\left.\mathrm{kg} \mathrm{ha}^{-1}\right)$ were in the $3^{\text {rd }}$ group. These results confirmed the conclusions of Lukow and McVetty (1991) and Tayyar (2010), that the yield is significantly affected by cultivar-effect.

\section{Figure 2: Comparing the effect of different forecrops and fertilizing treatments on Hardness Index} (Debrecen, Hungary, 2018)

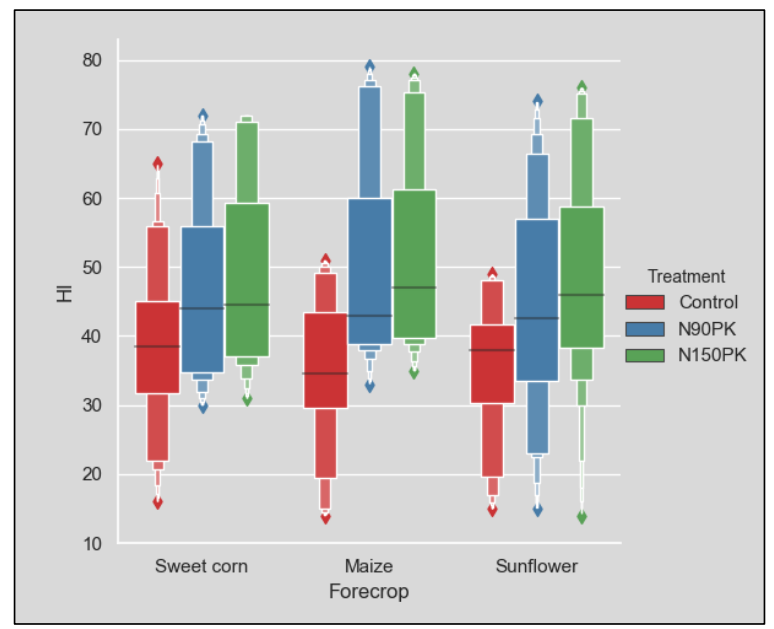

Results of Single Kernel Characterization System

Considering the results of the first experiment, both fertilizing dosages significantly increased kernel weight $\left(\mathrm{N}_{90} \mathrm{PK}\right.$ : $\left.45.51 \mathrm{mg}, \mathrm{N}_{150} \mathrm{PK}: 45.04 \mathrm{mg}\right)$ and hardness index $\left(\mathrm{N}_{90} \mathrm{PK}: 47.3, \mathrm{~N}_{150} \mathrm{PK}: 49.8\right)$ compared to the control samples (KW: $42.55 \mathrm{mg}$, HI: 36.2) (Table $1)$, however fertilizing had no significant effect on kernel diameter (data not shown). Forecrop had no significant effect on $\mathrm{KW}, \mathrm{KD}$ and $\mathrm{HI}$, in contrast samples grown after sweet corn had significantly higher KW compared to sunflower in control treatments (Figure 2), thereby the results of KW did not correlate with Borghi et al. (1995). Ingenio had significantly bigger KW (52.36 mg) and KD (3.35 mm) compared to other genotypes. Mv Ispán had significantly higher Hardness Index (65.3), while Hyland had significantly lower HI (28.3) and KD (2.9 $\mathrm{mm})$. Mv Ispán had significantly higher HI with sweet corn forecrop (sweet corn: 57, hard; maize: 49.5, transition; sunflower: 48, transition) on control treatment, in contrast this difference between the forecrops disappeared with fertilizing. Studying the hardness index of Hyland, with control treatment HI did not differed between the forecrops, but with fertilizing the samples with sunflower as previous crop reacted less. Also, fertilizing x cultivar (***), forecrop $\mathrm{x}$ treatment $(* *)$ and fertilizing $\mathrm{x}$ forecrop $\mathrm{x}$ cultivar (**) interaction had significant effect on Hardness Index. Moreover, fertilizing $\mathrm{x}$ cultivar $(* * *)$ and forecrop $\mathrm{x}$ cultivar $(* *)$ interaction had significant effect on Kernel Diameter. 
Effect of forecrops, fertilizing treatments and cultivar (experiment 1, forecrop: sweet corn) (Debrecen, Hungary, 2018)

\begin{tabular}{|c|c|c|c|c|c|c|c|c|c|c|c|c|c|c|c|c|}
\hline \multirow{2}{*}{$\stackrel{\vec{\Xi}}{\stackrel{\Xi}{\Xi}}$} & \multirow[b]{2}{*}{ Forecrop } & \multicolumn{3}{|c|}{$\begin{array}{l}\text { Hardness } \\
\text { Index }\end{array}$} & \multicolumn{3}{|c|}{$\begin{array}{c}\text { NIR-Protein } \\
(\%)\end{array}$} & \multicolumn{3}{|c|}{$\begin{array}{c}\text { NIR-Wet gluten } \\
(\%)\end{array}$} & \multicolumn{3}{|c|}{$\begin{array}{l}\text { Kernel weight } \\
\text { (mg) }\end{array}$} & \multicolumn{3}{|c|}{$\begin{array}{c}\text { Yield } \\
\left(\mathrm{kg} \mathrm{ha}^{-1}\right)\end{array}$} \\
\hline & & 芞 & 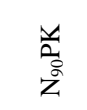 & $\begin{array}{l}\frac{v}{0} \\
\frac{n}{Z} \\
z\end{array}$ & 吕 & $\begin{array}{l}\frac{v}{2} \\
\text { zू }\end{array}$ & $\frac{v}{D_{0}}$ & 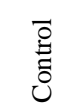 & $\begin{array}{l}\frac{v}{2} \\
\text { Z }\end{array}$ & 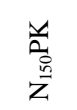 & 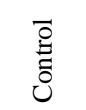 & $\frac{v}{2}$ & $\begin{array}{l}\frac{v}{D} \\
\frac{n}{Z} \\
Z\end{array}$ & 怘 & $\begin{array}{l}\text { va } \\
\text { Zू } \\
\text { ż }\end{array}$ & $\begin{array}{l}\frac{v}{n} \\
\frac{n}{z} \\
z\end{array}$ \\
\hline \multirow{3}{*}{ 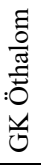 } & Sweet corn & 40.50 & 50.50 & 53.00 & 8.44 & 12.65 & 13.74 & 16.86 & 27.14 & 29.75 & 41.55 & 43.50 & 42.65 & 5795 & 7216 & 6425 \\
\hline & Maize & 38.75 & 49.50 & 53.50 & 9.37 & 11.72 & 13.63 & 18.49 & 25.16 & 29.50 & 42.90 & 45.13 & 46.13 & 2219 & 6509 & 7745 \\
\hline & Sunflower & 40.00 & 49.00 & 52.50 & 7.07 & 11.91 & 12.91 & 12.86 & 24.93 & 27.48 & 35.38 & 44.68 & 44.90 & 3610 & 6046 & 7821 \\
\hline \multirow{3}{*}{ 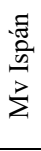 } & Sweet corn & 57.00 & 68.50 & 71.00 & 10.38 & 13.15 & 13.81 & 19.91 & 26.93 & 28.60 & 42.28 & 41.30 & 40.58 & 6806 & 8871 & 8505 \\
\hline & Maize & 49.50 & 76.75 & 76.00 & 8.87 & 13.62 & 13.45 & 15.88 & 28.50 & 27.88 & 39.53 & 39.80 & 39.73 & 2027 & 7486 & 8361 \\
\hline & Sunflower & 48.00 & 68.00 & 73.00 & 9.59 & 12.28 & 13.36 & 17.05 & 24.61 & 27.83 & 39.58 & 42.03 & 42.45 & 2714 & 8710 & 8708 \\
\hline \multirow{3}{*}{$\begin{array}{l}\stackrel{0}{\Xi} \\
\stackrel{0}{D} \\
\Xi \\
\Xi\end{array}$} & Sweet corn & 36.25 & 35.50 & 36.75 & 11.40 & 13.76 & 14.25 & 22.21 & 28.38 & 29.71 & 51.43 & 54.08 & 53.45 & 6010 & 7816 & 7488 \\
\hline & Maize & 32.50 & 39.75 & 40.25 & 10.23 & 13.12 & 13.97 & 18.81 & 26.80 & 29.18 & 49.83 & 53.63 & 53.10 & 2084 & 7203 & 7782 \\
\hline & Sunflower & 30.50 & 37.50 & 39.75 & 9.14 & 12.85 & 13.67 & 15.94 & 26.11 & 28.01 & 47.63 & 54.18 & 53.90 & 4168 & 7448 & 8734 \\
\hline \multirow{3}{*}{ 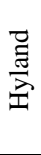 } & Sweet corn & 21.00 & 34.00 & 35.00 & 9.53 & 12.32 & 12.64 & 17.41 & 24.70 & 25.68 & 40.33 & 41.30 & 40.18 & 6556 & 9270 & 8264 \\
\hline & Maize & 17.75 & 36.50 & 38.25 & 8.14 & 12.23 & 12.44 & 14.04 & 24.40 & 24.63 & 40.78 & 42.50 & 41.25 & 2458 & 6650 & 8760 \\
\hline & Sunflower & 22.00 & 21.75 & 28.75 & 9.38 & 9.95 & 11.18 & 16.91 & 18.80 & 21.51 & 39.48 & 44.05 & 42.18 & 3071 & 8017 & 8206 \\
\hline \multicolumn{2}{|r|}{ LSD 5\% (Cv): } & \multicolumn{3}{|c|}{3.677} & \multicolumn{3}{|c|}{0.939} & \multicolumn{3}{|c|}{2.427} & \multicolumn{3}{|c|}{1.217} & \multicolumn{3}{|c|}{2209} \\
\hline & $\mathrm{LSD} 5 \%(\mathrm{Fc}):$ & \multicolumn{3}{|c|}{6.453} & \multicolumn{3}{|c|}{0.832} & \multicolumn{3}{|c|}{2.130} & \multicolumn{3}{|c|}{2.180} & \multicolumn{3}{|c|}{1818} \\
\hline & LSD 5\% (Tr): & \multicolumn{3}{|c|}{6.011} & \multicolumn{3}{|c|}{0.508} & \multicolumn{3}{|c|}{1.277} & \multicolumn{3}{|c|}{2.124} & \multicolumn{3}{|c|}{1139} \\
\hline
\end{tabular}

Abbreviations: $\mathrm{Cv}=$ cultivar, $\mathrm{Fc}=$ forecrop, $\mathrm{Tr}=$ fertilizing treatment.

Both fertilizing treatments significantly increased the Hardness Index compared to control samples (control: 44.67, $\left.\mathrm{N}_{90} \mathrm{PK}: 53.69, \mathrm{~N}_{150} \mathrm{PK}: 55.06\right)$ in the $2^{\text {nd }}$ experiment. Fertilizing had no significant influence on KW and KD (Table 2). Ingenio had significantly the highest KD and KW (52.98 $\mathrm{mg}, 3.36 \mathrm{~mm}$, respectively), while Vyckor had significantly the smallest kernels (KW: $37.14 \mathrm{mg}$, KD: $2.86 \mathrm{~mm}$ ). Vyckor and Hyland had significantly smaller kernel diameters compared to other genotypes. Also, Vyckor had significantly the hardest kernels (HI: 68.33) compared to the others, except Mv Ispán (HI: 65.5). Besides, statistically the softest kernels belonged to Hybiza, Hyland and Ingenio (HI: 32.83, 30.0, 36.17, respectively). GK Öthalom belonged to the transition types at control treatment, however with fertilizing to the hard types. Ingenio belonged to the transition group with all the 3 treatments, also the Hardness Index of this cultivar did not change observably with fertilizing. With control treatment the two hybrid varieties fell into the soft types, although with fertilizing they belonged to the transition group. All the other cultivars were hard types with any treatments. Cultivar $\mathrm{x}$ treatment interaction significantly affected the $\mathrm{HI}(* * *)$.

\section{Results of Mininfra NIT grain analyser}

The relevant data given in Table 1, which showed that in the $1^{\text {st }}$ experiment forecrop, fertilizing and cultivar had significant influence on protein and wet gluten values. Both fertilizing dosages significantly improved P (control: $9.29 \%, \mathrm{~N}_{90} \mathrm{PK}$ : $12.46 \%, \mathrm{~N}_{150} \mathrm{PK}$ : $13.25 \%$ ) and $\mathrm{WG}$ (control: $17.2 \%, \mathrm{~N}_{90} \mathrm{PK}: 25.54 \%$, $\mathrm{N}_{150} \mathrm{PK}: 27.48 \%$ ). Samples grown after sweet corn had significantly higher $\mathrm{P}(12.17 \%)$ and $\mathrm{WG}(24.77 \%)$ values compared to sunflower $(11.11 \%, 21.84 \%$, respectively), because the deep root system of sunflower exploits the nutrient and water supplies of the soil. Moreover, sweet corn and maize increased significantly $\mathrm{P}$ and $\mathrm{WG}$ than sunflower with $\mathrm{N}_{90} \mathrm{PK}$ fertilizing dosage. So, our results confirmed the findings of Borghi et al. (1995), but did not correlate with the statements of Stoeva and Ivanova (2009). Ingenio had the best protein $(12.47 \%)$ and wet gluten (25.02\%) values, however Hyland had the lowest $\mathrm{P}$ $(10.87 \%)$ and WG (20.9\%) values, but it was not statistically provable. Treatment $\mathrm{x}$ cultivar (**) and treatment $\mathrm{x}$ cultivar $\mathrm{x}$ forecrop $(*)$ interaction had significant influence on $\mathrm{P}$ and $\mathrm{WG}$.

In the $2^{\text {nd }}$ experiment both fertilizing dosages increased significantly $\mathrm{P}$ (control: $10.15 \%, \mathrm{~N}_{90} \mathrm{PK}$ : 13.2\%, $\mathrm{N}_{150} \mathrm{PK}: 13.74 \%$ ) and $\mathrm{WG}$ (control: $19.83 \%$, $\mathrm{N}_{90} \mathrm{PK}: 27.52 \%, \mathrm{~N}_{150} \mathrm{PK}: 28.86 \%$ ), so confirmed the conclusions of Linina and Ruza (2012) and Litke et al. (2018). In quality aspect, the highest $\mathrm{P}(13.88 \%)$ and WG $(29.33 \%)$ values belonged to KG Kunhalom, it had significantly better quality than Vyckor, GK Öthalom, Hybiza and Hyland. Statistically the lowest protein $(11.29 \%)$ belonged to Hybiza, while Hyland and 
Hybiza had significantly the lowest wet glutens (22.6\%, 22.81\%, respectively). These findings are in consonance with Lukow and McVetty (1991) and
Tayyar (2010). Cultivar and treatment interaction significantly affected protein content $(*)$.

Effect of fertilizing treatments and cultivar (experiment 2), Debrecen, 2018

\begin{tabular}{|c|c|c|c|c|c|c|c|}
\hline Cultivar & Treatment & $\begin{array}{c}\text { Yield } \\
\left(\mathrm{kg} \mathrm{ha}^{-1}\right)\end{array}$ & $\begin{array}{l}\text { Hardness } \\
\text { index }\end{array}$ & $\begin{array}{l}\text { NIR-Protein } \\
\quad(\%)\end{array}$ & $\begin{array}{l}\text { NIR-Wet } \\
\text { gluten (\%) }\end{array}$ & $\begin{array}{c}\text { Kernel } \\
\text { weight }(\mathrm{mg})\end{array}$ & $\begin{array}{c}\text { Kernel } \\
\text { diameter } \\
(\mathrm{mm})\end{array}$ \\
\hline \multirow{3}{*}{ GK Öthalom } & Control & 5795 & $40.50(\mathrm{~T})$ & 8.44 & 16.86 & 41.55 & 3.07 \\
\hline & $\mathrm{N}_{90} \mathrm{PK}$ & 7216 & $50.50(\mathrm{H})$ & 12.65 & 27.14 & 43.50 & 3.08 \\
\hline & $\mathrm{N}_{150} \mathrm{PK}$ & 6425 & $53.00(\mathrm{H})$ & 13.74 & 29.75 & 42.65 & 3.06 \\
\hline \multirow{3}{*}{ Mv Ispán } & Control & 6806 & $57.00(\mathrm{H})$ & 10.38 & 19.91 & 42.28 & 3.00 \\
\hline & $\mathrm{N}_{90} \mathrm{PK}$ & 8871 & $68.50(\mathrm{H})$ & 13.15 & 26.93 & 41.30 & 2.96 \\
\hline & $\mathrm{N}_{150} \mathrm{PK}$ & 8505 & $71.00(\mathrm{H})$ & 13.81 & 28.60 & 40.58 & 2.92 \\
\hline \multirow{3}{*}{ Ingenio } & Control & 6010 & $36.25(\mathrm{~T})$ & 11.40 & 22.21 & 51.43 & 3.33 \\
\hline & $\mathrm{N}_{90} \mathrm{PK}$ & 7816 & $35.50(\mathrm{~T})$ & 13.76 & 28.38 & 54.08 & 3.39 \\
\hline & $\mathrm{N}_{150} \mathrm{PK}$ & 7488 & $36.75(\mathrm{~T})$ & 14.25 & 29.71 & 53.45 & 3.37 \\
\hline \multirow{3}{*}{ Hyland } & Control & 6556 & $21.00(\mathrm{~S})$ & 9.53 & 17.41 & 40.33 & 2.87 \\
\hline & $\mathrm{N}_{90} \mathrm{PK}$ & 9270 & $34.00(\mathrm{~T})$ & 12.32 & 24.70 & 41.30 & 2.87 \\
\hline & $\mathrm{N}_{150} \mathrm{PK}$ & 8264 & $35.00(\mathrm{~T})$ & 12.64 & 25.68 & 40.18 & 2.86 \\
\hline \multirow{3}{*}{ GK Csillag } & Control & 6417 & $56.25(\mathrm{H})$ & 9.79 & 20.60 & 37.98 & 2.94 \\
\hline & $\mathrm{N}_{90} \mathrm{PK}$ & 8267 & $63.25(\mathrm{H})$ & 13.52 & 29.70 & 40.98 & 3.03 \\
\hline & $\mathrm{N}_{150} \mathrm{PK}$ & 8759 & $66.50(\mathrm{H})$ & 14.20 & 31.05 & 38.85 & 2.97 \\
\hline \multirow{3}{*}{ Mv Nádor } & Control & 6126 & $54.75(\mathrm{H})$ & 10.62 & 20.60 & 46.85 & 3.13 \\
\hline & $\mathrm{N}_{90} \mathrm{PK}$ & 7689 & $60.50(\mathrm{H})$ & 13.58 & 27.86 & 47.38 & 3.13 \\
\hline & $\mathrm{N}_{150} \mathrm{PK}$ & 7890 & $62.00(\mathrm{H})$ & 14.03 & 29.11 & 47.73 & 3.14 \\
\hline \multirow{3}{*}{ KG Kunhalom } & Control & 5829 & $53.00(\mathrm{H})$ & 11.38 & 23.10 & 43.80 & 3.11 \\
\hline & $\mathrm{N}_{90} \mathrm{PK}$ & 7617 & $61.00(\mathrm{H})$ & 14.98 & 32.11 & 46.55 & 3.15 \\
\hline & $\mathrm{N}_{150} \mathrm{PK}$ & 7154 & $61.00(\mathrm{H})$ & 15.29 & 32.76 & 45.00 & 3.12 \\
\hline \multirow{3}{*}{ Vyckor } & Control & 7507 & $56.75(\mathrm{H})$ & 10.36 & 19.68 & 37.50 & 2.89 \\
\hline & $\mathrm{N}_{90} \mathrm{PK}$ & 9167 & $73.50(\mathrm{H})$ & 12.75 & 25.90 & 36.93 & 2.85 \\
\hline & $\mathrm{N}_{150} \mathrm{PK}$ & 9186 & $74.75(\mathrm{H})$ & 13.40 & 27.69 & 37.00 & 2.85 \\
\hline \multirow{3}{*}{ Hybiza } & Control & 7569 & $26.50(\mathrm{~S})$ & 9.46 & 18.09 & 44.23 & 2.96 \\
\hline & $\mathrm{N}_{90} \mathrm{PK}$ & 9172 & $36.50(\mathrm{~T})$ & 12.06 & 24.95 & 44.23 & 2.97 \\
\hline & $\mathrm{N}_{150} \mathrm{PK}$ & 8879 & $35.50(\mathrm{~T})$ & 12.34 & 25.39 & 43.65 & 2.97 \\
\hline \multicolumn{2}{|c|}{ LSD 5\% (Cultivar): } & 1763 & 4.807 & 1.454 & 3.652 & 1.294 & 0.038 \\
\hline \multicolumn{2}{|c|}{ LSD 5\% (Treatment): } & 772 & 6.971 & 0.528 & 1.335 & 2.224 & 0.073 \\
\hline
\end{tabular}

Abbreviations: $(\mathrm{H})=$ hard; $(\mathrm{T})=$ transition; $(\mathrm{S})=$ soft.

\section{Pearson's correlation analysis}

Using Pearson's correlation analysis results (Table $3)$, we can state that NIR-P $\left(0.784^{* *}\right)$ and NIR-WG $\left(0.783^{* *}\right)$ were in tight positive; yield $\left(0.717^{* *}\right)$ was in medium positive, while Hardness Index $\left(0.315^{* *}\right)$ was in loose positive correlation with fertilizing treatment. Besides, NIR-WG $(0.989 * *)$ was in tight positive, yield $(0.703 * *)$ and HI $(0.519 * *)$ were in medium positive correlation with NIR-P. This correlation between HI and NIR-P confirmed the findings of Groos et al. (2004). Besides, the positive tight correlation between yield and NIR-P is in contrast with Garrido-Lestache et al. (2004). Suprisingly, KW had no statistical relationship with yield, but Hardness index was in negative loose correlation with $\mathrm{KW}(-0.313)$, however $\mathrm{KD}$ and $\mathrm{KW}$ was in tight positive correlation $\left(0.918^{* *}\right)$. 
Result of Pearson's correlation analysis (Debrecen, Hungary, 2018)

\begin{tabular}{|c|c|c|c|c|c|c|c|}
\hline & Treatment & KW & $\mathrm{KD}$ & $\mathrm{HI}$ & NIR-P & NIR-WG & Yield \\
\hline Treatment & 1 & & & & & & \\
\hline Kernel weight & $.166^{*}$ & 1 & & & & & \\
\hline Kernel diameter & .034 & $.918^{* *}$ & 1 & & & & \\
\hline Hardness index & $.315^{* *}$ & $-.313^{* *}$ & $-.205^{* *}$ & 1 & & & \\
\hline NIR-Protein & $.784 * *$ & $.319^{* *}$ & $.210^{* *}$ & $.519 * *$ & 1 & & \\
\hline NIR-Wet gluten & $.783 * *$ & $.287^{* *}$ & $.200^{* *}$ & $.544 * *$ & $.989 * *$ & 1 & \\
\hline Yield & $.717 * *$ & .064 & -.143 & $.389 * *$ & $.703 * *$ & $.704 * *$ & 1 \\
\hline
\end{tabular}

*. Correlation is significant at the 0.05 level.

**. Correlation is significant at the 0.01 level.

\section{CONCLUSION}

The object of our experiment was to study the effect of basic agrotechnical factors. In two experiments, we examined the effect of different fertilizing treatments, forecrops and cultivars on yield, Hardness Index, kernel weight, kernel diameter, NIR-protein and NIRwet gluten content. Fertilizing had significant effect on yield, KW, HI, NIR-P and NIR-WG, except KD. As stated by Chantret et al. (2005), kernel hardness is an inherited property, although to complement this with that, fertilizing can improve it to a certain extent as our and Luo et al. (2000) results proved it. According to our data of correlation analysis, there was no negative relationship between yield and NIR-P, although the yield of some genotypes (Vyckor, GK Csillag and Mv Nádor) increased with $\mathrm{N}_{150} \mathrm{PK}$ dosage as well, while we did not realize any yield improving effect above $\mathrm{N}_{90} \mathrm{PK}$ dosage on the other varieties (GK Öthalom, Hybiza, Hyland, Ingenio, KG Kunhalom and Mv Ispán), but studying the results of NIR-P we could see that increasing fertilizing dosage had significant influence. If we confront our and Litke et al. (2018) conclusions, where they recommended $180 \mathrm{~kg} \mathrm{ha}^{-1} \mathrm{~N}$ for maximum yield, and $210 \mathrm{~kg} \mathrm{ha}^{-1} \mathrm{~N}$ for protein, we can see that in the case of yield, $\mathrm{N}_{90} \mathrm{PK}$ dosage would be enough to realize the yield potential for 6 out of 9 cultivars, but considering protein content - as main quality criteria $\mathrm{N}_{150} \mathrm{PK}$ was needed. These results are in agreement with Pepó (2011), that the usage of fertilizers is affected significantly by nutrient reactionary properties of the cultivated genotypes. As advised by many researchers, before starting wheat growing the selection of right cultivar and agrotechnical practices has to depend on the targeted market (animal feed or industrial use). Forecrop had no statistical influence on yield, KW, KD or HI, however sweet corn as previous crop had significant improving effect on NIR-P and NIR-WG compared to sunflower. There were some significant differences between the effect of forecrops only at $\mathrm{N}_{90} \mathrm{PK}$ treatment, where maize and sweet corn as forecrop increased significantly the NIR-P and NIRWG compared to sunflower. Vyckor variety had the highest average yield $\left(8620 \mathrm{~kg} \mathrm{ha}^{-1}\right)$, but in quality aspect, the highest average NIR-P (13.88\%) and NIRWG $(29.33 \%)$ values belonged to KG Kunhalom variety. Considering hybrid varieties, Hybiza and Hyland performed well in the aspect of yield $(8450 \mathrm{~kg}$ $\mathrm{ha}^{-1}, 8030 \mathrm{~kg} \mathrm{ha}^{-1}$, respectively), but had significantly the lowest NIR-WG values $(22.6 \%, 22.81 \%$, respectively).

Summarizing our findings, quality and yield of winter wheat were significantly affected by fertilizing, forecrop and cultivar. As we reported sweet corn created much more favourable conditions as a forecrop than maize or sunflower. On the basis of our results, we see reasonable to continue the experiment to extend the research with year effect.

\section{ACKNOWLEDGEMENTS}

We are grateful to Cereal Research Non-profit Ltd., Szeged for providing us the instruments, also to Látókép Experimental Farm of University of Debrecen for providing us the wheat samples.

\section{REFERENCES}

Ágoston, T.-Pepó, P. (2005): Évjárathatás vizsgálata őszi búzafajták termésére és termésstabilitására, Agrártudományi Közlemények $16 ., 62-67$.

Asthir, B.-Jain, D.-Kaur, B.-Bains N. S. (2017): Effect of nitrogen on starch and protein content in grain influence of nitrogen doses on grain starch and protein accumulation in diversified wheat genotypes, Journal of Environmental Biology Vol. 38, 427-433.
Borghi, B.-Corbellini, M.-Minoia, C.-Palumbo, M.-Di Fonzo, N.Perenzin, M. (1997): Effects of mediterranean climate on wheat bread-making quality, Europ. J. of Agron. 6, 145-154.

Chantret, N.-Salse, J.-Sabot, F.-Rahman, S.-Bellec, A.-Laubin, B.Dubois, I.-Dossat, C.-Sourdille, P.-Joudrier, P.-Gautier, M. F.Cattolico, L.-Beckert, M.-Aubourg, S.-Weissenbach, J.Caboche, M.-Bernard, M.-Leroy, P.-Chalhoub, B. (2005): Molecular basis of evolutionary events that shaped the Hardness 
locus in diploid and polyploid wheat species (Triticum and Aegilops). Plant Cell 17: 1033-1045.

Eliasson, A.-Larsson, K. (1993): Flour, In: Cereals in Breadmaking: a Molecular Colloidal Approach. Marcel Dekker, New York.

Garrido-Lestache, E.-López-Bellido, R. J.-López-Bellido, L. (2004): Effect of $\mathrm{N}$ rate, timing and splitting and $\mathrm{N}$ type on bread-making quality in hard red spring wheat under rainfed Mediterranean conditions, Field Crops Research 85, 213-236.

Groos, C.-Bervas, E.-Charmet, G. (2004): Genetic analysis of grain protein content, grain hardness and dough rheology in a hard $\mathrm{x}$ hard bread wheat progeny, J. of Cereal Science 40, 93-100.

Győri, Z.-Győriné, I. M. (1998): A búza minősége és minősítése, Mezőgazdasági Szaktudás Kiadó, Budapest.

Hajdu, M. (1977): A növénytermelö technikusok kézikönyve, Mezőgazdasági Kiadó, Budapest.

Horváth, Cs.-Kis, J.-Tarnawa, Á.-Kassai, K.-Nyárai, H.-Jolánkai, M. (2014): The effect of nitrogen fertilization and crop year precipitation on the protein and wet gluten content of wheat (Triticum aestivum L.) grain. Agrokémia és Talajtan, 63 (1). 159-164.

Linina, A.-Ruza, A. (2012): Cultivar and nitrogen fertiliser effects on fresh and stored winter wheat grain quality indices, Proceedings of the Latvian Academy of Sciences Vol. 66., 177184.

Litke, L.-Gaile, Z.-Ruza, A. (2018): Effect of nitrogen fertilization on winter wheat yield and yield quality, Agronomy Research 16 (2), 500-509.

Lukow, O. M.-McVetty, P. B. E. (1991): Effect of cultivar and environment on quality characteristics of spring wheat, Cereal Chem. 68 (6), 597-601.

Luo, C.-Branlard, G.-Griffin, W. B.-McNeil, D. L. (2000): The Effect of Nitrogen and Sulphur Fertilisation and their Interaction with Genotype on Wheat Glutenins and Quality Parameters, Journal of Cereal Science 31, 185-194.

Mendiburu, F. D. (2019): agricolae: Statistical Procedures for Agricultural Research. R package v. 1.3-1.

Montemurro, F.-Convertini, G.-Ferri, D. (2007): Nitrogen application in winter wheat grown in Mediterranean conditions: effects on nitrogen uptake, utilization efficiency, and soil nitrogen deficit, Journal of Plant Nutrition 30., 1681-1703.
Pasha, I.-Anjum, F. M.-Morris, C. F. (2010): Grain Hardness: a major determinants of wheat quality, Food Sci. and Techn. Int. $16,511-522$.

Pepó, P. (2011): Role of genotypes and agrotechnical elements in cereal crop models, Cereal Research Communications 39 (1), 160-167.

Pepó, P. (2016): Correlation between fertilization and baking quality of winter wheat cultivars, Columella - Journal of Agricultural and Environmental Sciences Vol. 3 (2), 15-23.

Pepó, P. (2018): Experiment summary of 2018, University of Debrecen.

Preston, K. R.-Williams, P. C. (2003): Analysis of wheat flour, in Encyclopedia of Food Sciences and Nutrition (Second Edition), 2543-2550.

Ragasits, I. (1998): Búzatermesztés, Mezőgazda Kiadó Budapest, 19-140.

Shi, Y.-Yu, Z.-Wang, D.-Li, Y.-Wang, Y. (2007): Effects of nitrogen rate and ratio of base fertilizer and topdressing on uptake, translocation of nitrogen and yield in wheat, Front. Agric. China 1 (2), 142-148.

Stoeva, I.-Ivanova, A. (2009): Interaction of the technological properties of common winter wheat varieties with some agronomy factors. Bulg. J. Agric. Sci. 15, 417-422.

Szabó, P. B. (2009): Módszerek búza szemkeménységének meghatározására, Doktori értekezés, Budapesti Corvinus Egyetem.

Tayyar, S. (2010): Variation in grain and quality of Romanian bread wheat varieties compared to local varieties in northwestern Turkey, Romanian Biotechnological Letters Vol. 15, No. 2, 5189-5196.

Tóthné, P. L. (2011): A kutatásmódszertan matematikai alapjai, Eszterházy Károly Főiskola.

Walsh, O. S.-Shafian, S.-Christiaens, R. J. (2018): Nitrogen fertilizer management in dryland wheat cropping system, Plants 7 (9), 111.

Wickham, H.-François, R.-Henry, L.-Müller, K. (2019): dplyr: A Grammar of Data Manipulation. R package v. 0.8.3. 
